\title{
The Toxicity Effect of Detergent on Enzymatic and Protein Activities of African Mud Catfish (Clarias gariepinus)
}

\author{
Nkpondion NN ${ }^{1}$, Ugwumba OA ${ }^{1}$ and Esenowo IK ${ }^{2 *}$ \\ ${ }^{1}$ Department of Zoology, University of Ibadan, Ibadan, Nigeria \\ ${ }^{2}$ Department of Zoology, University of Uyo, Akwa Ibom, Nigeria
}

\begin{abstract}
The toxicities of commercial detergent (Ariel; Linear Alkylbenzene Sulfonate), a household cleaning agent was investigated on some enzymatic and protein activities of juvenile African mud catfish (Clarias gariepinus). Fishes were exposed to lethal and sub-lethal concentrations of detergent for 21 days in a renewal bioassay procedure. The median lethal concentrations $\left(\mathrm{LC}_{50}\right)$ were derived using Finney probit method while protein and enzymatic activities were determined using Biuret and Randox methods respectively. The $\mathrm{LC}_{50}$ values for 96 hours acute bioassay test was 0.11 $g / l$. Detergent exposed fish showed significant increase $(p \leq 0.05)$ in serum AST $(109.00 \pm 3.79$ to $111.00 \pm 3.80)$; liver globulin at $0.008 \mathrm{~g} / \mathrm{l}(2.47 \pm 0.03)$ and $0.013 \mathrm{~g} / \mathrm{l}(2.57 \pm 0.03)$. Significant decrease was recorded in liver AST, (ALP and creatinine $137 \pm 4.67$ to $151 \pm 2.52 ; 80.67 \pm 0.88$ to $86.67 \pm 3.67$ and $0.27 \pm 0.07$ to $0.60 \pm 0.00$ respectively across all sub- lethal concentrations. The enzymes and proteins from serum, liver and heart tissues of fish have shown vividly that detergent is capable of inducing adverse effects and impacting on the health of fish. Therefore, the presence of detergent in aquatic ecosystem could be dangerous to fish and subsequently human health.
\end{abstract}

Keywords: Toxicity; Detergent; Enzymes; Plasma proteins; Clarias gariepinus

\section{Introduction}

Detergents contain traces of iron, manganese and zinc. They are cleaning products derived from synthetic organic chemicals with the ability to foam when used in acid or hard water [1]. In commercial detergents, the surfactant which are mainly responsible for the cleaning action include bleach, filler, foam, stabilizer, builder, perfume, soil suspending agents, enzymes, dyes, optical brighteners and other materials designed to enhance the cleaning action of the surfactant [1]. There are various types of surfactants used in detergents formulation; the linear alkylbenzene sulfonate (LAS)-ionia surfactants is most widely used [2]. This was introduced as biodegradable alternative to the non-biodegradable branched-chained alkylbenzene sulfonates [3]. LAS have been reported to have a high solid adsorption coefficient, which is attributed to the physico-chemical properties of the surfactants [4]. The LAS molecules absorb to the suspended solid in water bodies and hence end up in sediments along the water course or sludge in treatment plants [5].

The recommended LAS that were claimed by some researchers to biodegrade perfectly have also been reported to poorly degrade in rivers, lakes, ponds, and even in soils. This may be toxic to aquatic flora and fauna and can also induce severe damage to vital organs and even haematological, hormonal and enzymatic disturbances [6-8]. It has also been discovered that detergent surfactants increases microbial population especially those that are able to use the surfactants as their basic source of carbon or phosphate or both, some of these microorganisms stand as ectoparasites and endoparasites that cause histological degradation in fish species [9].

Detergents are widely used in both industrial and domestic premises to wash equipment, installations, heavy duty machines, vehicles and oilsoiled materials. Detergent is a persistent environmental contaminant probably due to its use in the formulation of cleaning agents, pesticides and for dispersing oil spills at seas. Detergents, including the biodegrading ones have been discovered to induce poisonous effects and osmo-regulatory imbalance in aquatic lives especially if present in concentration that exceed metabolic demand [10]. Such xenobiotic compounds could be persistent and more mobile in soil and water hence; they are known to be among of the most common terrestrial and aquatic contaminants [11]. The detergent effluents and discharges have also been noticed to induce severe damage to such vital organs like gills, liver, kidney, skin, heart and brain [12-17]. Previous studies reported that indiscriminate deposition of effluents/toxicants into an aquatic ecosystem might decrease the dissolved oxygen concentration, which stand to impair respiration leading to asphyxiation (which is an indication of unconsciousness or death produced by failure of blood to become properly oxygenated in lungs) and may ultimately result into organ architectural degradation such as liver dysfunction.

Types of damage to a tissue can have significant effect. For example, mild inflammation to the cells will likely increase the permeability of the cell membrane and allow cytoplasmic enzymes to leak out into the blood, whereas in case of cell necrosis, both cytoplasmic and mitochondrial enzymes will be detected in the blood. Alterations in ALT (Alanine transaminase), ALP (Alkaline phosphatise), AST (Aspartate transaminase) activities of fish resulting from toxicant or contamination effect in various organs of fish have been reported [18]. Such biochemical changes in fish are aimed at maintaining equilibrium in the presence of these toxicants, which are known to disrupt physiological and biochemical processes [19]. According to Das and Mukherjee, exposure of fish for a long time to most toxicants interferes with protein metabolism. Decrease in total protein in fish exposed to toxic levels of toxicant could be attributed to either a state of hydration and change in water equilibrium in the fish or a disturbance in liver

*Corresponding author: Esenowo IK, Department of Zoology, University of Uyo, Akwa Ibom, Nigeria, Tel: +2348036671097; E-mail: imehesenowo@yahoo.com

Received February 23, 2016; Accepted March 26, 2016; Published March 31 2016

Citation: Nkpondion NN, Ugwumba OA, Esenowo IK (2016) The Toxicity Effect of Detergent on Enzymatic and Protein Activities of African Mud Catfish (Clarias gariepinus). J Environ Anal Toxicol 6: 361. doi:10.4172/2161-0525.1000361

Copyright: ( 2016 Nkpondion NN, et al. This is an open-access article distributed under the terms of the Creative Commons Attribution License, which permits unrestricted use, distribution, and reproduction in any medium, provided the original author and source are credited. 
protein synthesis or both [20]. All biological activities are regulated by enzymes and hormones which are also proteins. Assessment of protein and enzyme activities can be considered as a diagnostic tool to determine the physiological status of cell or tissues [21].

Fishes are widely used to evaluate the health of aquatic ecosystem; and physiological changes serve as biomarkers of environmental pollution [22]. C. gariepinus is most widely used because; it is able to tolerate both well and poorly oxygenated waters and respires bimodally [23]. Fish physiology (Biochemical blood parameters and metabolic enzymes) are suitable tools for assessing environmental influences and stress effects of anthropogenic origin on the condition and health of aquatic vertebrates [24]. Since there is close association between the circulatory system of fish and the external environment [25] the effect of external stressors and toxic substances on exposed fish could be made manifest through clinical diagnosis of fish physiology, hence the need for this study.

\section{Materials and Methods}

\section{Specimen collection}

Healthy juveniles of African catfish species, Clarias gariepinus [26] with mean weight $17.23 \pm 3.59 \mathrm{~g}$ and mean standard length $13.7 \pm 0.9$ $\mathrm{cm}$ were obtained from the Oyo State Fish Farms, Mokola, Ibadan and transported in unaerated container to the laboratory. The fishes were acclimatized for at least two weeks during which they were fed with dried commercial fish food containing $40 \%$ crude protein at $2.5 \%$ of body weight twice daily. Clarias gariepinus was selected based on availability of species, adaptability to laboratory conditions, convenient handling size, in-depth knowledge of species biology and ecology, biological significance and economic values [27].

\section{Measurement of physico-chemical parameters of water}

The physico-chemical parameters of water determined were Temperature, pH, Dissolved Oxygen (DO), Biological Oxygen Demand (BOD) and Conductivity. Temperature was measured using a mercury glass thermometer. $\mathrm{pH}$ was measured using Jenway $\mathrm{pH}$ meter. DO, BOD and Conductivity were determined by methods described by APHA [28].

\section{Bioassay techniques}

The bioassay for the acute and sub-lethal toxicity tests was carried out in five, 50 litre plastic containers. After a series of range finding tests a static renewal bioassay procedure [29] was adopted in which the test media were regularly renewed every 24 hours at the same set of concentrations. A preliminary investigation was carried out to determine the definitive concentrations suitable for testing toxicants as described by Solbe [27]. The concentrations used for the acute toxicity test were $0.02 \mathrm{~g} / \mathrm{L}, 0.04 \mathrm{~g} / \mathrm{L}, 0.06 \mathrm{~g} / \mathrm{L}, 0.08 \mathrm{~g} / \mathrm{L}$ as well as control $(0.00$ $\mathrm{g} / \mathrm{L}$ ) while that of the sub-lethal test were in the order of $0.025 \mathrm{~g} / \mathrm{L}$, $0.013 \mathrm{~g} / \mathrm{L}, 0.008 \mathrm{~g} / \mathrm{L}$ and $0.00 \mathrm{~g} / \mathrm{L}$ (control). In all treatments, ten fully acclimatized test organisms were held and the same in control stock, as described by Rahman and Solbe [27,30].

\section{Blood sampling}

After 21 days, three fishes from each tank were randomly caught gently with hand net in order to avoid/minimize handling stress. The mucus and water from the body of the fish were dried off using a clean cloth. Fish head was wrapped in a towel to allow for better grip. Blood was taken from the vein running ventrally along the vertebral column using $1 \mathrm{ml}$ sterile plastic syringes equipped with a $26 \mathrm{G}$ hypodermic needle. The blood was transferred into EDTA Heparinized tubes and was immediately taken to clinical pathology laboratory of the Department of Veterinary Pathology, University of Ibadan for analyses. The serum was then removed by subjecting the tubes to centrifugation at 3000 rpm for $5 \mathrm{~min}$ and then stored at $-80^{\circ} \mathrm{C}$ until further analyses. After blood collection, fishes were immediately sacrificed and the desired organs (liver and heart) were removed to prepare post-mitochondrial fractions for the probable enzymatic and biochemical analyses.

\section{Preparation of post-mitochondrial fraction (supernatants)}

The liver and heart were immediately excised and rinsed in ice-cold $1.15 \% \mathrm{KCl}$ buffer, blotted on filter paper and weighed appropriately. The tissues were them macerated and homogenized in four volumes of homogenizing buffer ( $\mathrm{pH}$ 7.4) using laboratory mortar and pestle. The homogenized tissues were later centrifuged at $3000 \mathrm{~g}, 4^{\circ} \mathrm{C}$ for 10 minutes and the supernatant obtained was aliquoted and stored at $-20^{\circ} \mathrm{C}$ for biochemical analysis.

\section{Biochemical parameters analyses}

Albumin, Creatinine Globulin, Aspartic Amino Transferase (AST), Alanine Amino Transferase (ALT), Alkaline Phosphatase (ALP), glucose, cholesterol and total protein were determined by kits of Randox Company. The measurement of albumin was based on its quantitative binding to the indicator 3,3', 5,5'- tetrabromo-m cresol sulphonepthalein (bromocresol green, BCG). The albumin-BCGcomplex absorbs maximally at $578 \mathrm{~nm}$, the absorbance being directly proportional to the concentration of albumin in the sample. Creatinine in alkaline solution reacts with picric acid to form a coloured complex. The amount of the complex formed is directly proportional to the creatinine concentration and this was determined using a spectrophotometer at wavelength capability of 490 to $510 \mathrm{~nm}$. Alanine Aminotransferase (ALT) was measured by monitoring the concentration of pyruvate hydrazone formed with 2,4 dinitrophenyldrazine. The absorbance of the complex formed was read after 5 minutes using spectrophotometer at a wavelength of 530-550 nm. The absorbance represents the level of ALT. Aspartate Aminotransferase (AST) was measured by monitoring the concentration of oxaloacetate formed with 2,4 dinitrophenyldrazine. The absorbance of the complex formed was read after 5 minutes using spectrophotometer at a wavelength between $530-550 \mathrm{~nm}$ and it represents the level of AST.

\section{ALP analysis followed the principle:}

p-nitrophenylphophate $+\mathrm{H}_{2} 0 \rightarrow$ phosphate + p-nitrophenol

Total protein was determined using the Biuret reaction. A violet coloured complex was produced by reacting the proteins and peptides with an alkaline copper sulphate solution. The optical density (O.D) of the samples was measured against reagent blank using a spectrophotometer with readings taken between 530 and $565 \mathrm{~nm}$.

\section{Statistical analysis}

Toxicological concentration data involving quantal response (mortality) for the acute tests were analyzed by probit analysis [31]. The indices of toxicity measurement derived from this analysis were:

$\mathrm{LC}_{5}=$ Sub-lethal concentration that causes $5 \%$ response (Mortality) of exposed organisms.

$\mathrm{LC}_{50}=$ Median concentration that causes $50 \%$ response (Mortality) of exposed organisms.

$\mathrm{LC}_{95}=$ Lethal concentration that causes $95 \%$ response (Mortality) of exposed organism and their $95 \%$ 
Confidence Limits. One way Analysis of Variance (ANOVA) was used to test for statistical difference in the enzymatic and plasma protein composition. Duncan Multiple Ranges Test (DMRT) was used in determination of significance at 0.05 level of probability.

\section{Results}

The mean values for the physic-chemical parameters of $\mathrm{pH}$, dissolved oxygen, temperature, conductivity, biological oxygen demand were $7.58 \pm 0.04,9.20 \pm 0.30 \mathrm{mg} / \mathrm{L}, 27 \pm 0.03^{\circ} \mathrm{C}, 181 \pm 1.20 \mu \mathrm{Sc} /$ $\mathrm{cm}$ and $185.78 \pm 0.07 \mathrm{mg} / \mathrm{L}$ respectively.

No adverse behavioural changes or mortality were recorded in the control experiment throughout the period of the bioassay. While in detergent treated fishes, several abnormal behavioural responses were observed and recorded. These responses included incessant jumping and gulping for air, restlessness, frequent surface to bottom movement, sudden change of direction during movement, resting at the bottom, loss of skin colouration, loss of equilibrium and gradual onset of inactivity. Feeding was also reduced in the organisms. Toxicity of detergent increased with increased concentration. Linear relationship between the probit mortality and the log concentration indicated a positive relationship (Table 1).

There was significant decrease $(p \leq 0.05)$ in the serum AST level of fish exposed to $0.008 \mathrm{~g} / \mathrm{l}$ of detergent with mean values $48.00 \pm 0.58$ when compared with the control with mean values $52.00 \pm 1.15$. There was also a significant decrease in liver AST level of exposed fish across all concentrations ranging from $137 \pm 4.67$ to $151 \pm 2.52$ as compared with control with mean values $154.00 \pm 4.51$. However, there was no significant change in the heart AST level of exposed fish across all concentrations of detergent as compared with fish in the control tank. There was no significant change in the ALT levels of serum, liver, and heart of fish exposed to all sub-lethal concentrations of detergent when compared with the control. There was a significant increase $(\mathrm{p} \leq 0.05)$ in the serum ALP levels with mean values ranging from $109.00 \pm 3.79$ to $111.00 \pm 3.80$ across all concentrations of exposed fish as compared with control with mean values of $89.69 \pm 4.33$. Also there was a significant increase $(\mathrm{p} \leq 0.05)$ in heart ALP levels with mean values ranging from $86.00 \pm 2.00$ to $100.33 \pm 0.67$ across all concentrations of exposed fish as compared with control having mean values of 54.00 \pm 13.00 . However, there was a significant decrease $(p \leq 0.05)$ in the liver ALP levels of exposed fish across all sub-lethal concentrations of detergent with mean values ranging from $80.67 \pm 0.88$ to $86.67 \pm 3.67$ as compared with control having mean values of $144.00 \pm 3.50$ (Table 2).

There was however no significant difference in the levels of serum, liver and heart total protein of fish exposed to all sub-lethal concentrations of detergent. There was also no significant difference in the albumin levels in the serum, liver and heart of fish across all concentrations of fish exposed to detergent. There was a significant increase $(\mathrm{p} \leq 0.05)$ in the liver globulin level at sub-lethal concentrations of $0.008 \mathrm{~g} / \mathrm{l}$ with mean values $2.47 \pm 0.03$ and $0.013 \mathrm{~g} / \mathrm{l}$ with mean values $2.57 \pm 0.03$ as compared with control having mean values of $1.87 \pm 0.03$ in the detergent exposed fish. There was a significant decrease $(\mathrm{p} \leq 0.05)$ in liver creatinine level of fish exposed to all sub-lethal concentrations of detergent ranging from $0.27 \pm 0.07$ to $0.60 \pm 0.00$ as compared with control having mean values $0.63 \pm 0.19$ (Table 3 ).

\section{Discussion}

Under stress conditions, body mechanisms are altered to combat the effect of the pollutants/stressors in order to stabilize the organism [32]. Fish under stress mobilize triglycerides and protein to meet an increased demand for energy resulting from increased physical activity, bio-transformation and excretion of xenobiotic [23]. Behavioural abnormalities have been attributed to nervous impairment as a result of blockage of nervous transmission between the nervous systems and various effectors' sites, enzyme dysfunctions that may induce paralysis of respiratory muscles and/ or depressions of respiratory centre and disturbances in energy or metabolic pathways which result

\begin{tabular}{|c|c|c|c|c|c|}
\hline Exposure Time & $\mathrm{LC}_{50}(95 \% \mathrm{CL}) \mathrm{g}^{-1}$ & $\mathrm{LC}_{95}(95 \% \mathrm{CL}) \mathrm{g}^{-1}$ & $\mathrm{LC}_{5}(95 \% \mathrm{CL}) \mathrm{g}^{-1}$ & Slope \pm SE & Probit Equation \\
\hline $24 \mathrm{Hrs}$ & 0.111 & 0.22 & 0.06 & $5.40 \pm 0.79$ & $y=10.15+5.40 x$ \\
\hline $48 \mathrm{Hrs}$ & 0.090 & 0.22 & 0.04 & $4.15 \pm 0.47$ & $y=9.34+4.15 x$ \\
\hline $72 \mathrm{Hrs}$ & 0.087 & 0.22 & 0.03 & $4.01 \pm 1.03$ & $y=9.25+4.01 x$ \\
\hline $96 \mathrm{Hrs}$ & 0.111 & 0.33 & 0.04 & $3.45 \pm 1.43$ & $y=8.29+3.45 x$ \\
\hline
\end{tabular}

Table 1: Acute mortality test of Clarias gariepinus exposed to lethal concentrations of detergent for 96 hours.

\begin{tabular}{|c|c|c|c|c|c|c|c|c|c|}
\hline \multirow{2}{*}{$\begin{array}{c}\text { Concentration } \\
(\mathrm{g} / \mathrm{l})\end{array}$} & \multicolumn{3}{|c|}{ ALT $(\mu \mathrm{l})$} & \multicolumn{3}{|c|}{ AST $(\mu \mathrm{l})$} & \multicolumn{3}{|c|}{ ALP $(\mu \mathrm{l})$} \\
\hline & Liver & Serum & Heart & Liver & Serum & Heart & Liver & Serum & Heart \\
\hline Control $(0.00)$ & $32.67 \pm 1.20^{a}$ & $30.67 \pm 0.33^{a}$ & $29.67 \pm 1.20^{a}$ & $144.00 \pm 3.50^{\mathrm{a}}$ & $89.67 \pm 4.33^{a}$ & $54.00 \pm 13.00^{\mathrm{a}}$ & $154.00 \pm 4.51^{c}$ & $52.00 \pm 1.15^{d}$ & $145.67 \pm 0.33^{a}$ \\
\hline 0.008 & $31.33 \pm 0.88^{a}$ & $28.67 \pm 0.89^{a}$ & $32.67 \pm 0.33^{a}$ & $86.67 \pm 3.67^{a}$ & $109.00 \pm 3.79^{b}$ & $86.00 \pm 2.00^{\mathrm{b}}$ & $132.33 \pm 7.33^{a}$ & $48.00 \pm 0.58^{a}$ & $142.00 \pm 1.53^{a}$ \\
\hline 0.013 & $30.33 \pm 1.85^{a}$ & $31.67 \pm 0.89^{b}$ & $28.00 \pm 1.00^{a}$ & $80.67 \pm 0.88^{a}$ & $111.00 \pm 3.80^{b}$ & $100.33 \pm 0.67^{b}$ & $151.00 \pm 2.52^{\mathrm{bc}}$ & $53.33 \pm 1.50^{b}$ & $143.00 \pm 1.53^{a}$ \\
\hline 0.025 & $30.00 \pm 0.58^{a}$ & $28.67 \pm 1.50^{\mathrm{a}}$ & $32.67 \pm 2.19^{a}$ & $83.33 \pm 12.84^{a}$ & $108.00 \pm 2.00^{b}$ & $97.67 \pm 3.84^{b}$ & $137.00 \pm 4.67^{\mathrm{ab}}$ & $54.33 \pm 2.40^{b}$ & $147.00 \pm 5.84^{a}$ \\
\hline
\end{tabular}

Table 2: Means and standard deviation of enzyme levels of Clarias gariepinus exposed to detergent for 21 days.

\begin{tabular}{|c|c|c|c|c|c|c|c|c|c|c|c|c|}
\hline \multirow{2}{*}{$\begin{array}{c}\text { Concentration } \\
(\mathbf{g} / \mathbf{l})\end{array}$} & \multicolumn{3}{|c|}{ Albumin $(\mu \mathrm{l})$} & \multicolumn{3}{|c|}{ Globulin $(\mu \mathrm{l})$} & \multicolumn{3}{|c|}{ Creatinine $(\mu \mathrm{l})$} & \multicolumn{3}{|c|}{ Plasma Protein } \\
\hline & liver & serum & heart & liver & serum & heart & liver & serum & heart & liver & serum & heart \\
\hline Control & $1.67 \pm 0.13^{a}$ & $3.00 \pm 0.20^{\mathrm{a}}$ & $1.07 \pm 0.27^{\mathrm{a}}$ & $\begin{array}{l}1.87 \pm \\
0.03^{\mathrm{a}}\end{array}$ & $\begin{array}{c}3.70 \pm \\
0.40^{\mathrm{a}}\end{array}$ & $\begin{array}{c}1.63 \pm \\
0.13^{\mathrm{a}}\end{array}$ & $\begin{array}{c}0.63 \pm \\
0.19^{b}\end{array}$ & $\begin{array}{c}0.60 \pm \\
0.00^{\mathrm{a}}\end{array}$ & $\begin{array}{c}0.47 \pm \\
0.67^{\mathrm{a}}\end{array}$ & $3.53 \pm 0.17^{a}$ & $6.67 \pm 0.52^{\mathrm{a}}$ & $3.13 \pm 0.32^{\mathrm{a}}$ \\
\hline 0.008 & $1.27 \pm 0.03^{\mathrm{a}}$ & $2.47 \pm 0.70^{\mathrm{a}}$ & $1.10 \pm 0.20^{\mathrm{a}}$ & $\begin{array}{c}2.47 \pm \\
0.03^{\mathrm{a}}\end{array}$ & $\begin{array}{c}3.60 \pm \\
0.50^{\mathrm{a}}\end{array}$ & $\begin{array}{c}2.33 \pm \\
0.32^{\mathrm{a}}\end{array}$ & $\begin{array}{l}0.30 \pm \\
0.00^{\mathrm{ab}}\end{array}$ & $\begin{array}{c}0.67 \pm \\
0.33^{\mathrm{a}}\end{array}$ & $\begin{array}{c}0.37 \pm \\
0.03^{\mathrm{a}}\end{array}$ & $3.73 \pm 0.07^{\mathrm{a}}$ & $6.40 \pm 0.50^{\mathrm{a}}$ & $3.10 \pm 0.10^{\mathrm{a}}$ \\
\hline 0.013 & $1.30 \pm 0.10^{a}$ & $2.13 \pm 0.42^{\mathrm{a}}$ & $1.20 \pm 0.0^{\mathrm{a}}$ & $\begin{array}{c}2.57 \pm \\
0.03^{b}\end{array}$ & $\begin{array}{c}3.83 \pm \\
0.44^{\mathrm{a}}\end{array}$ & $\begin{array}{c}2.37 \pm \\
0.13^{\mathrm{a}}\end{array}$ & $\begin{array}{c}0.27 \pm \\
0.07^{\mathrm{a}}\end{array}$ & $\begin{array}{c}0.80 \pm \\
0.00^{\mathrm{a}}\end{array}$ & $\begin{array}{c}0.73 \pm \\
0.23^{\mathrm{a}}\end{array}$ & $3.96 \pm 0.09^{a}$ & $6.00 \pm 0.52^{\mathrm{a}}$ & $3.43 \pm 0.13^{a}$ \\
\hline 0.025 & $1.47 \pm 0.19^{a}$ & $1.83 \pm 0.30^{\mathrm{a}}$ & $1.87 \pm 0.33^{\mathrm{a}}$ & $\begin{array}{c}1.77 \pm \\
0.17^{\mathrm{a}}\end{array}$ & $\begin{array}{c}3.89 \pm \\
0.27^{\mathrm{a}}\end{array}$ & $\begin{array}{c}1.80 \pm \\
0.40^{\mathrm{a}}\end{array}$ & $\begin{array}{l}0.60 \pm \\
0.00^{\text {ab }}\end{array}$ & $\begin{array}{c}0.80 \pm \\
0.20^{\mathrm{a}}\end{array}$ & $\begin{array}{c}0.47 \pm \\
0.03^{a}\end{array}$ & $3.43 \pm 0.37^{\mathrm{a}}$ & $5.63 \pm 0.60^{a}$ & $3.67 \pm 0.07^{a}$ \\
\hline
\end{tabular}

Means with the same superscript letter in a column are not significantly different in the DMRT test $(P \leq 0.05)$.

Table 3: Means and standard deviation of Plasma protein Levels of Clarias gariepinus exposed to detergent for 21 days. 
in depletion of energy. The stressful and erratic behaviour of the fish in this investigation gives a signal to respiratory impairment and may be as a result of the effect of the detergent on the gills. This is in agreement with works of Adewoye et al. and Ayoola [15,17] and Ogundiran et al. Esenowo and Ugwumba $[2,8]$ of respiratory impairment of fish exposed to detergent. Hyperactivities observed in this study are attributed probably to the disturbances in the metabolic state resulting in the depletion of energy. It is possible that animals which have higher metabolic activities could require higher level of oxygen and thus would embark on higher respiratory activities. Lethargies and loss of equilibrium observed in this study may be due to depletion of energy in the body of the exposed fishes Also, lethargies and loss of equilibrium as recorded could indicate impairment of normal carbohydrate metabolism which is a possible result of enzymatic impairment. According to Anderson et al. [33], impairment of the carbohydrate metabolism results in the depletion of energy causing lethargies and loss of equilibrium and those organisms that cannot tolerate the toxicant enter into a state of coma and die. It was observed that the rate of mortality became greatly increased with increased concentration of detergent. This is in accordance with the report of Fryer [34] as regards all categories of toxicants.

ALT, AST, ALP are non plasma specific enzymes that are localized in tissue cells of liver, heart, gills, kidneys, muscles and other organs and their presence in the blood may give specific information about organ dysfunction [35]. Decrease in serum and liver AST level in detergent-exposed fish observed in this study suggests a decrease in energy demand, metabolic pathway and amino acids. The decrease in the activities of ALT and AST in the detergent-exposed fish corroborates the findings of Luskova et al. [36] in Cyprinus carpio exposed to diazinone but contradicts that of Tiwari and Singh [37] in Chana punctatus treated with sub-lethal levels of alcoholic extracts of Nerium indium. Adedeji et al. [38] reported that diazinone induced a significant decrease in blood alkaline phophatase acid phophatase of Clarias gariepinus whereas; ALT and AST were comparable in the control treated fishes. A decrease in the transaminases suggests that there was no tissue damage, the parenchymatous tissue and skeletal muscles being intact, but rather a decrease in the rate of transfer of the amine groups which eventually affects the rate of protein and carbohydrate synthesis in fish. The decrease in ALP level in the liver of detergent exposed fish could be attributed to a fall in the synthesis of glycogen caused by lowered metabolic demands and also due to electrolytic imbalance caused by tissue over dehydration. This is in accordance with the reports of Shaffi et al. [39] on the effects of starvation on tissues and serum ALP of Heteropneustes auriculata.

Plasma proteins which include albumin and globulin serve a vital function in carrying materials from one part of the body to another via circulation. The protein make up of an organism is of important diagnostic significance because of proteins involvement in enzymes, hormones and antibiotics as well as osmotic pressure balance and in maintaining acid-base balance [40]. Total protein levels may increase, decrease or exhibit no significant trend. In this study, the detergent exposed fish showed no significant trend in protein levels when compared with the control. This could be attributed to concentrations used and probably exposure period. Albumin is the most abundant protein in the plasma. It is synthesized in the liver at a rate that is dependent on protein intake subject to feed back regulation by plasma albumin level. Albumin is a useful indicator of the integrity of glomerular and other membranes. Its chief functions are to transport and store a wide variety of ligands to maintain the plasma oncotic pressure and to serve as a source of endogenous amino acids [41].
Proteins also include globulin some of which are produced in the liver while others are made by the immune system. Globulin is made up of subunits of $\alpha 1, \alpha 2, \beta$ and $\gamma$ globulins, which are considered as the source of almost all the immumologically active proteins in the blood [25]. Generally, increases in the levels of globulin in fish are thought to be associated with a stronger innate immune response [42]. The result of this study shows an increase in the liver globulin level of fish exposed to detergent which is an indication of the immune response of the fish in combating the toxicant. Creatinine is a biomarker of muscle purine metabolism, liver damage and kidney acid. In this study, creatinine levels however showed no significant difference. Hadi et al. [40] however reported an increase in creatinine level of Tilapia zillii exposed to Aluminium. It was also reported that increase in creatinine level might be induced by glomerular insufficiency, increased muscle tissue catabolism or the impairment of carbohydrate metabolism.

\section{Conclusion}

The exposure of $C$. gariepinus juvenile to even sub-lethal concentrations of detergent can induce various toxicological effects in the form of enzymatic degradation. It can be inferred that the presence of detergent in aquatic environment can induce enzymatic and organ damages, which might make all the living entities in polluted environment vulnerable to disease, and eventually lead to death. Therefore, enzymatic activities can be suitably used to determine the effect of detergent on the physiology of fish under sub-lethal condition prior to sudden death of the fish. General environmental quality monitoring should be compulsory and the monitoring of the quality of water be done on a regular basis and as a result, any abnormal changes in the physiology of the aquatic organisms can easily be detected and appropriate action taken before the outbreak of epidemics.

\section{References}

1. Okpokwasili GC, Nwabuzor CN (1988) Primary biodegradation of anionic surfactants in laundry detergents. Chemosphere 17: 2175-2182.

2. Esenowo IK, Ugwumba OA (2010) Growth Response of Catfish (Clarias gariepinus) Exposed to Water Soluble Fraction of detergent and diesel oil Environmental Research Journal 4: 298-301

3. Gledhill WE (1974) Linear alkylbenzene sulfonate: biodegradation and aquatic interactions. Adv Appl Microbiol 17: 265-293.

4. Painter HA, Zebel T (1989) The behaviour of LAS in sewage treatment. Tenside Sulfonates detergent 26: 108-115.

5. Cavalli LM, Cassani G, Pravettoni S, Nucci O, Larrizaria M, et al. (2000) Surfactants in sediments. Clear Review 6: 32-43.

6. Lightowlers $P(2004)$ Still dirty: A review of action against toxic products in Europe. A report for WWF-UK.

7. Ogundiran MA, Fawole OO, Adewoye SO (2007) Effect of soap and Detergent Effluents on Haematological profile of Clarias gariepinus. Science Focus 12: 84-88.

8. Ogundiran MA, Fawole OO, Adewoye SO, Ayandiran TA (2009) Pathologic Lesions in the Gills structures of Clarias gariepinus on exposure to sub-lethal concentrations of soap and detergent effluents. J Cell and Animal Biol 3: 078-082.

9. Eniola KIT, Olayemi AB (2000) Some Aspect Bacterial- Detergents interaction in freshwater environment. Bioscience Research Communication 14: 645-649.

10. Ezemonge LN, Ogeleka DF, Okieimon FE (2007) Acute Toxicity of Industrial Detergent (Neatex) and Corrosion Inhibitor (Norust CR486) to Early Stages of Cichlids (Tilapia guineensis). Chemistry and Ecology 23: 131-138.

11. Cox C (1998) Glophosphate (roundup). J Pestic Perform 18: 3-17

12. Abbas HHH (1998) Toxicological Effect of Copper and Lead on some aspects in two Fish species, Blue Tilapia (Oreochromis niloticus) and African Catfish (Clarias gariepinus). PhD Thesis, Faculty of Science, Cairo University, Egypt. 
Citation: Nkpondion NN, Ugwumba OA, Esenowo IK (2016) The Toxicity Effect of Detergent on Enzymatic and Protein Activities of African Mud Catfish (Clarias gariepinus). J Environ Anal Toxicol 6: 361. doi:10.4172/2161-0525.1000361

13. Abbas $\mathrm{HHH}$, Mahmood HM (2008) The Toxicological Effect of Water Pollution on the Nile Tilapia Fish (Oreochromise niloticus) collected from four sites along the River Nile. J Egypt vert Med Assoc 63: 307-323.

14. Abbas HHH, Mahmood HM (2004) Heamatology and Biochemical Changes in Oreochromise aureus and Clarias gariepinus exposed to mixture of copper and lead salts. Egypt J Basic Appl Physiol 3: 89-106.

15. Ayoola SO (2008) Toxicity of glyphosphate herbicide on Nile tilapia (Oreochromis niloticus) juvenile. Agric Res 3: 825-834.

16. Warren CE (1997) Biology and Water Pollution. WB Sanders and Company Philadelphia, USA, p: 434.

17. Adewoye SO, Fawole OO, Owolabi OD, Omotosho JS (2005) Toxicity of cassava waste water effluents of African Catfish: Clarias gariepinus. Ethiop $J$ Sci 28: 189-194.

18. Begum G (2004) Carbofuran insecticide induced biochemical alterations in live and muscle tissues of the fish Clarias batrachus (linn) and recovery response. Aquat Toxicol 66: 83-92.

19. Wedemeyer GA, Mcleay OJ (1981) Methods Assessing the Tolerance of Fishes to Environmental Stressors. In: Pickering AD (Ed) Stress in fish, Academic press, London, pp: 247-275.

20. Gluth G, Hanke W (1984) A comparison of physiological changes in carp Cyprinus carpio, induced by several pollutants at sublethal concentration--Il. The dependency on the temperature. Comp Biochem Physiol C 79: 39-45.

21. Manoj K (1999) Mercury, copper and cadmium induced changes in the total protein levels of muscle tissue of edible estuarine fish (Boleopthalmus dessumuri). Cuv J Env Bio 20: 231-234.

22. Kock G, Triendi M, Hofer R (1996) Seasonal pattern of metal accumulation in Arctic Char (Salvelinus alpines) from an oligotrophic Alpine lake related to temperature. Can J Fish Aquat Sci 53: 780-786.

23. Alkahem HF, Ahmed Z, Al-Akel AS, Shansi MJK (1998) Toxicity bioassay and changes in haematological parameters of Oreochromis niloticus induced by trichloroform. Arab Gulf J Sci Res 16: 581-585.

24. Celik ES (2004) Blood chemistry (electrolytes, lipoproteins and enzymes) values of black scorpion fish (Scorpaena porcus) in the Dardanelles. Turkey J Biol Sci 4: 716-719.

25. Cech JJ, Bartholow SD, Young PS, Hopkins TE (1996) Striped bass exercise and handling stress in fresh water: Physiological responses to recovery environment. Trans Am Fish Soc 125: 308-320.

26. Jha AG, Mekkawyl AA, Verreth J, Kirschbaum F (2007) Effects of lead nitrate on the activity of metabolic enzymes during early developmental stages of the African Catfish. Clarias gariepinus (Burchell, 1822) Fish Physiol Biochem 33: 1-13.
27. Solbe JF (1995) Freshwater In: Handbook of Ecotoxicology (Eds) Peter Collins. Blackwell Science limited. Osneymeed OX 20EL, p: 683.

28. APHA (2003) Standard methods for the examination of water and waste water American Public Health Association, $16^{\text {th }}$ (Edn), Washington DC, p: 1268.

29. ASTM (American Society for Testing of Materials) (1990) Guide for conducting acute toxicity test with fishes, Macroinvertebrates and amphibians.

30. Rahman MZ, Hossain ZM, Ellah MFR, Ahmed GU (2202) Effect of Diazinon $60 \mathrm{Ec}$ on Anabustes tudineus, Channa punctatus and barbades gomonous. Naga The ICLARM quarterly 25: 8-11.

31. Finney DJ (1978) Statistical Method in Biological Assay. 3rd edn. Griffin Press, London, p: 508.

32. Siva PRK (1980) Studies on some aspects of metabolic change with emphasis on carbohydrate utility in the cell free system of the teleost Tilapia mossambicus (peters) under methyl parathion exposure. PhD Thesis, SV University, Tirupati, India.

33. Anderson T, Forlin L, Hardig J, Larsson A (1988) Physiological disturbances in fish living in Coastal water polluted with bleached Kraft pulp mill effluents. Can J Fish Aquat Sci 45: 1525-1536.

34. Fryer JD (1977) Weed Control Handbook. Make Peace 1: 384-389.

35. Gabriel U, George ADI (2005) Plama enzymes in Clarias gariepinus exposed to chronic levels of roundup (glyphosate). Environ Ecolo 25: 271-276.

36. Luskova V, Svoboda M, Kolarova J (2002) The effects of diazinon on blood plasma biochemistry in carp (Cyprinus carpio). Act Vet Brno 71: 117-123.

37. Tiwari S, Singh A (2004) Piscidal activity of alcohol extract of Nerium indicum leaf and their biochemical stress response on fish metabolism. Afri J Trad CAM 1: 15-29.

38. Adedeji OB, Adeyemo OK, Agbede SA (2009) Effects of diazinon on blood parameters in the African catfish (Clarias gariepinus). Afr J Biotechnol 8: 3940-3946.

39. Shaffi SA (1975) Effects of starvation on tissue and serum gluconeogenic enzymes, alkaline phosphates and tissue glucogen in freshwater catfish Heteropnuestes fossilis (Bloch). Acta Physiol Sci Hung 53: 501-505.

40. Hadi A, Shoker A, Alwan S (2009) Effect of aluminium on the biochemical parameters of fresh water fish Tilapia zillii. J Sci Appl 3: 33-41.

41. Peters TJ (1975) Serum Albumin in the Plasma Protein. 2nd edn., Putnam F (Ed), York Academic Press, p: 133

42. Sastry KV, Gupta PK (1980) Alterations in the activities of a few dehydrogenase in the digestive system of two teleost fishes exposed to lead nitrate. Ecotoxicol Environ Saf 4: 232-239. 